\title{
BROADCAST REGULATION AND THE IRRELEVANT LOGIC OF STRICT SCRUTINY
}

\author{
R. George Wright *
}

\section{INTRODUCTION}

For decades, legal regulation of the content ${ }^{1}$ of broadcast $^{2}$ television entertainment ${ }^{3}$ programs has looked for guidance to the case of Federal Communications Commission v. Pacifica Foundation. ${ }^{4}$ Whatever its precise scope

* Lawrence A. Jegen Professor of Law, Indiana University School of Law-Indianapolis.

1. For purposes of this Article, I set aside ways in which the FCC might regulate entertainment broadcast television apart from programming content, such as with regard to assigned broadcast frequency, digitalization rules, and other such matters. For discussion of the murky distinction between content-based and content-neutral restrictions on speech, see R. George Wright, Content-Based and Content-Neutral Regulation of Speech: The Limitations of a Common Distinction, 60 U. MIAM1 L. REV. 333 (2006) [hereinafter The Limitations of a Common Distinction].

2. The legal standards for media such as pay cable television or paid access via telephone to particular kinds of entertainment content have departed from those for broadcast television. See, e.g., United States v. Playboy Entm't Grp., 529 U.S. 803, 813 (2000) (applying strict scrutiny to content-based statutory regulation of signal bleed, incomplete scrambling, or hours restriction of sexually explicit cable television channels); Sable Commc'n v. FCC, 492 U.S. 115, 130-31 (1989) (denial of adult access to "indecent" but not obscene commercial telephone messages, for the sake of denying minors access to such messages, as not sufficiently narrowly tailored to such a purpose).

3. We shall thus set aside issues associated with regulation of the content of broadcast television news and explicit, formal opinion and editorializing of a traditional narrow sort, as discussed in cases such as Red Lion Broad. Co. v. FCC, 395 U.S. 367, 400-01 (1969) (constitutionally upholding certain aspects of the socalled "Fairness Doctrine"). See generally Syracuse Peace Council v. FCC, 867 F.2d 654 (D.C. Cir. 1989) (commentary on the "faimess doctrine"); Symposium, Does Red Lion Still Roar? Public Interest Media Regulation Forty Years After Red Lion Broadcasting Co. v. FCC, 60 ADMIN. L. REV. 767, 767-909 (2008) (noted scholars discuss the legacy of the "faimess doctrine").

4. 438 U.S. 726 (1978) (5-4 plurality opinion, with two Justices partially concurring and concurring in the result over two separate dissenting opinions by a total of four Justices). Pacifica itself addressed not a broadcast television program, but an afternoon FM radio broadcast of a phonograph record by George Carlin. See id. at 751-55 (transcript of Carlin's broadcast). But it is indisputable that at least as of this moment, Pacifica remains the central and authoritative case for first amendment limits on federal regulation of broadcast television entertainment programming, especially with regard to minor children, whether the regulatory concern focuses on violent programming, sexual programming, or both. For merely a few prominent examples of Pacifica's role in such television regulation cases, see, e.g., the largely administrative law-based case of Fox Television Stations, Inc. v. FCC, 129 S. Ct. 1800 (2009); the circuit court opinion of the Fox case and Judge Leval's constitutionally-focused dissent, Fox Television Stations, Inc. v. FCC, 489 F.3d 444 (2d Cir. 2007); and the subsequent circuit court opinion following the Supreme Court's remand, Fox Television Stations, Inc. v. FCC, 613 F.3d 317, 330 (2d Cir. 2010) (decided on vagueness grounds). See also Petition of the FCC and the United States for Rehearing and Rehearing En Banc, Fox Television Stations, Inc. v. FCC, 613 F.3d 317 (2d Cir. 2010), (No. 06-1760), 2010 WL 3463628 (citing Pacifica throughout). For an example of a controversial Pacifica-influenced case involving broadcast television from outside the Fox context, see the opinions of the divided en banc court in Action For Children's Television v. FCC, 58 F.3d 654 (D.C. Cir. 1995) (en banc) (7-4 decision) (discussing the television and radio broadcasting hours of 
and holding, ${ }^{5}$ however, Pacifica has not inspired complete approval among commentators ${ }^{6}$ or the courts. ${ }^{7}$ This Article reassesses and ultimately rejects the Pacifica case as a framework for broadcast entertainment television content regulations. I reject Pacifica even assuming that the decision was intended to promote the welfare of children, parental decision-making authority, and the broader public well-being. ${ }^{8}$ Any worthy interests that are significantly promoted by Pacifica and related cases must be shown, and not merely assumed, to exist. Realistically, given recent developments in media technology and culture, there is simply no such interest.

My rejection of Pacifica does not primarily take the form of concern over any undue vagueness, ${ }^{9}$ nor is my concern primarily focused on what are called issues of "narrow tailoring." 10 That is, my main concern is not with whether the broadcast television regulation in question could be "narrower" or less restrictive of the broadcaster's speech, while still promoting the cited governmental interest just as well. My primary concern is thus not with the conventional questions courts normally focus on in the course of "strict scrutiny" 11 of a typical content-based regulation of speech: the precise weight of the cited government interest, and the degree of tailoring of the regulation to the promotion of that interest. ${ }^{12}$ Instead, my initial focus is on inquiring, as best we can, into the actual existence or nonexistence of a substantial governmental interest at stake in Pacifica-type cases. I will ask what kinds and degrees of effects the regulated broadcast programming itself tends to have. ${ }^{13}$ In this, I will be mainly guided not by speculation or intuitive assumptions, but rather by the available social science. ${ }^{14}$

'indecent' material and the interests of children).

While we will discuss throughout this Article the realistic availability and the alleged adverse effects of several other communications media and technologies, we will not attend more than fleetingly to broadcast radio, given the relative lack of current peer-reviewed scholarly studies of broadcast radio in this respect. For some loosely related speculative possibilities, consider the prospect of Howard Stern's departure from SiriusXM satellite subscription radio to a model of monthly fee-based Internet podcasts. See Jere Hester, Online Stern Could be a Net Gain For Fans, available at http://www.nbcwashington.com/entertainment/celebrity/Online-Stem-Could-be-a-Net-Gain-For-Fans-

102477654.html (September 8, 2010) (last visited Apr 13, 2011). Whether on SiriusXM satellite radio or via Internet podcasts, Howard Stern would of course remain largely beyond current FCC broadcast regulatory jurisdiction for speech content. See, e.g., Spencer Osborne, Court Say FCC Indecency Standard Violate First Amendment, available at http://siriusbuzz.com/court-say-fcc-indecency-standards-violate-firstamendment.php (July 14, 2010) (last visited April 23, 2011).

5. See generally FCC v. Pacifica, 438 U.S. 726 (1978).

6. See sources cited infra note 90 .

7. See infra text accompanying notes 66-72.

8. See infra Section III.

9. See infra text accompanying notes 78-82.

10. On issues of narrow tailoring, including its remarkable manipulability, see R. George Wright, How Do Courts Legitimize What They Do? The Fourteen Faces of Narrowness, 31 LoY. L.A. L. REV. 167, 187 (1997).

11. On the strict scrutiny of content-based regulations, see The Limitations of a Common Distinction, supra note 1 , at 335 .

12. See id.

13. See infra Sections III. B. and III. C.

14. See infra Section III. C. For a useful exploration of the question of the appropriate forms and degrees of evidence of causation of particular sorts of harms before a speech regulation might be considered justified, see Clay Calvert \& Matthew D. Bunker, Free Speech, Fleeting Expletives, and the Causation Quagmire: Was 
Even more importantly, I focus on questions of the realistic effectiveness of typical broadcast television regulations in promoting the typically cited governmental interests in our own contemporary technological and cultural environment. ${ }^{15}$ In other words, do Pacifica-type regulations really solve the problems typically cited by government regulators? There is little point, beyond futile symbolism, in citing a governmental interest, drafting a broadcast speech regulation, and carefully avoiding broad regulatory language, if the regulation does not genuinely advance the cited interest to a sufficient degree. ${ }^{16}$ Content-based regulations of speech should not simply be assumed to be effective in practice.

This Article concludes, based on the developing evidence, that typical Pacifica-style content regulations of broadcast television speech simply fail to meaningfully promote the typically cited regulatory interests in question. ${ }^{17}$ Today, and likely moreso in the future, technological and cultural trends conspire against the effectiveness of Pacifica-style broadcast regulations.

The crucial development is that, increasingly, any one readily accessible communication technology conveniently substitutes for another. The ability of federal regulation to effectively prevent children and young adults from accessing, via one communications technology or another, broadcast material or its equivalent that is deemed inappropriate is already minimal and is rapidly diminishing. Culture and technology have outpaced the sort of regulation in question, and rendered such regulations ineffective.

Simply put, even the most carefully drafted restrictions of such broadcast speech should be declared unconstitutional if the government cannot sufficiently show that its interests will genuinely be sufficiently advanced in practice. Children and young adults of various ages, however, now gain convenient access through one technological means or another to the programming that typical Pacifica-type regulations seek to bar to them. Such broadcast regulations burden broadcaster speech without adequately promoting any sufficient governmental interest. The government could theoretically seek to impose Pacifica-type regulations on any and all communication media. But the sheer impracticality, intrusiveness, and unenforceability of most such regulations, today and in the future, rule out such a course.

In pursuing these themes, I first introduce some of the most relevant Pacifictype judicial cases addressing the regulation of broadcast television entertainment programs. ${ }^{18} \mathrm{I}$ briefly sample some of the law review and other literature critiquing or defending such regulations ${ }^{19}$ in order to establish current legal sentiment in this regard. Eventually, this Article refers to highlights of the social science literature ${ }^{20}$ and other related critiques to get a sense of what can be validly claimed regarding

\footnotetext{
Justice Scalia Wrong in Fox Television Stations?, 47 SAN DIEGO L. REV. 737 (2010).

15. See infra Sections III. B. and III. D.

16. See infra Section III.

17. See infra Section III. B.

18. See infra Section II.

19. See sources cited infra notes 58-59, 90 .

20. See infra Sections III. C. and III. D.
} 
the direction and extent of some of (broadcast) television's effects. Concluding, for example, that broadcast television is somehow associated, even causally, with something we call "aggression" might in some contexts and for some purposes tell us something of value. This Article also acknowledges the possibility of public interests, tracing back to the discussions of Plato, ${ }^{21}$ that may strike many as relevant and significant, but which may also be difficult to prove ${ }^{22}$ in any reasonably politically neutral way. But all of these concerns turn out, in our own context, to be of at most only secondary importance.

This Article instead focuses on the rapidly evolving phenomena by which broadcast entertainment, or its equivalent, is readily transferred, conveyed, or otherwise migrates, to other media. ${ }^{23}$ Some of the media in question are no less accessible to children and young adults than familiar television sets, with or without parental V-chips. For some such media, the realistic prospects for legally regulating content for child and young adult viewers, without impairing the viewing choices of mature adults, ${ }^{24}$ are minimal. As a result, Pacifica-type broadcast regulations are now obsolete and ineffective. A brief Conclusion then calls for appropriate reform of Pacifica and related broadcast standards, and responds to objections. ${ }^{25}$

\section{II. $P A C I F I C A$ AND THE CURRENT State of THE LAW}

\section{A. Pacifica Itself}

The plurality opinion in Pacifica ${ }^{26}$ is unclear in its reach and scope. Throughout the opinion, it curiously reads like a point-by-point response to the nonmedia draft protest case of Cohen v. California. ${ }^{27}$ Pacifica also builds, unfortunately, on the shifting sands of then-current communications technology by relying in part on the technological analysis of the prior Red Lion fairness doctrine case. ${ }^{28}$ Pacifica, an "indecency" rather than a "violence" or "aggression" case, begins by asserting that the FCC's statutory authority to regulate "indecent" broadcast speech is not confined to speech that appeals to a "prurient" interest in sex $^{29}$ - that is, to an interest in sex that is purportedly shameful, morbid, excessive, or presumably abnormal. ${ }^{30}$ This operates to broaden the scope of what might be construed as "indecent," as much purportedly "indecent" language is actually non-

\footnotetext{
21. See infra Section III. D.

- 22. See id.

23. See infra Section III. B.

24. See, e.g., Butler v. Michigan, 352 U.S. 380, 383-84 (1957) (holding that state's obscene literature statute was overly broad and "bum[ed] the house to roast the pig").

25. See infra Section IV.

26. Pacifica, 438 U.S. at 726.

27. 403 U.S. 15 (1971) (involving one particular message, among others, inscribed on the defendant's jacket in the presence of a public courthouse).

28. See Red Lion, 395 U.S. at 367

29. See Pacifica, 438 U.S. at 741.

30. See Brockett v. Spokane Arcades, Inc., 472 U.S. 491, 504-05 (1985) ("prurience may be constitutionally defined for the purposes of identifying obscenity as that which appeals to a shameful or morbid interest in sex").
} 
sexual. $^{31}$

As for the practical free speech value of indecent language, the Pacifica Court declares that "[a] requirement that indecent language be avoided will have its primary effect on the form, rather than the content, of serious communication. There are few, if any, thoughts that cannot be expressed by the use of less offensive language." 32 One's message or point can, on this view, be imparted in roughly equivalent fashion through either "decent" or "indecent" means. Regardless of whether we find this view persuasive, it was anticipated and rebutted in Cohen. The Court asserted that "much linguistic expression serves a dual communicative function: it conveys not only ideas capable of relatively precise detached explication, but otherwise inexpressible emotions as well. In fact, words are often chosen as much for their emotive force as their cognitive force." ${ }^{33}$ If we believe that the Court was right in Cohen, similar reasoning would logically apply in Pacifica or a broadcast television case. In Cohen, the Court had concluded that "we cannot indulge the facile assumption that one can forbid particular words without also running a substantial risk of suppressing ideas in the process." ${ }^{34}$ It is again hard to see why similar reasoning should not apply in Pacifica or in the broadcast television context. ${ }^{35}$

The Court in Pacifica then conceded that the regulation of George Carlin's "Filthy Words" monologue was based, as least partly, on the content of the speech in question. ${ }^{36}$ But the fine was not, the Court argued, imposed based on any disagreement with the political ideas expressed by the monologue, ${ }^{37}$ and was therefore in that sense not based on the content. Rather, the fine was based on a combination of the distinctive way in which the ideas were expressed, ${ }^{38}$ and the time, context, or circumstances of the radio broadcast in question. ${ }^{39}$

The plurality indulged in a distinction between Carlin's message and the means of conveying that message. As to the means of expression, the plurality further announced that "it is undisputed that the content of Pacifica's broadcast was 'vulgar,' 'offensive,' and 'shocking,",40 whether one agreed or disagreed with any

31. See, e.g., Fox Television Stations v. FCC, 613 F.3d 317, 323 (2d Cir. 2010) (the televised awards ceremony broadcast observations of Nicole Ritchie on the subject of purse sanitization provides an especially instructive example).

32. Pacifica, 438 U.S. at 743 n. 18.

33. Cohen, 403 U.S. at 26.

34. $1 d$.

35. But see Pacifica, 438 U.S. at 743 n.18 ("A requirement that indecent language be avoided will have its primary effect on the form, rather than the content, of serious communication. There are few, if any, thoughts that cannot be expressed by the use of less offensive language").

36. See id. at 744 ("It is . . clear that the [FCC]'s objections to the broadcast were based in part on its content").

37. See id. at $745-46$ ("If there were any reason to believe that the [FCC]'s characterization of the Carlin monologue as offensive could be traced to its political content... First Amendment protection might be required").

38. In contrast, the argument that the state had no objection to any political ideas expressed by the symbolic flag burning at issue in the case did not prevail in Texas v. Johnson, 491 U.S. 397 (1989).

39. See Pacifica, 438 U.S. at $746-51$.

40. Id. at 747 . 
accompanying message. It would not be much of an exaggeration to say that today, more than three decades later, what would be "shocking" would be a lack of dispute over whether Carlin's monologue is vulgar, offensive, and shocking. The Court in Cohen anticipates and rebuts the Pacifica plurality in this respect as well. Generally, the Cohen majority argues "so long as the means are peaceful, the communication need not meet standards of acceptability." 41

More vividly, the Court in Cohen concludes that while Cohen's language was "perhaps more distasteful than most others of its genre, it is nevertheless often true that one man's vulgarity is another's lyric." ${ }^{42}$ There is here in Cohen an element of relativism or subjectivism that is later unrecognized or denied in Pacifica. But Cohen can also be read to add a further, relevant concern for principled, consistent judicial enforcement as well: "it is largely because government officials cannot make principled distinctions in this area that the Constitution leaves matters of taste and style so largely to the individual." 43

Pacifica, in contrast, seeks to account for much of the difference in our reactions to language as merely reflecting differences in context, ${ }^{44}$ setting, ${ }^{45}$ and circumstance. ${ }^{46}$ Crucially, the broadcast media are said in Pacifica to have a "uniquely pervasive presence in the lives of all Americans." 47 The supposedly pervasive broadcast media often presents listeners or viewers with unexpected material in their private home or vehicle. ${ }^{48}$

In such contexts, "[t]o say that one may avoid further offense by turning off the radio ... is like saying that the remedy for an assault is to run away after the first blow." 49 This is, of course, the remedy left to anyone who is surprised and offended by encountering the constitutionally protected message of Cohen's jacket in a more public courtroom or corridor. ${ }^{50}$ Such persons, according to Cohen, "could effectively avoid further bombardment of their sensibilities simply by averting their eyes."

The Court in Pacifica then referred to the broadcast media as "uniquely accessible to children," 52 distinguishing other forms of expression to which children but not adults may be denied access. ${ }^{53}$ With respect to children, the Court had previously recognized two distinct government interests: first, in the well-being

41. Cohen, 403 U.S. at 25 (quoting Organization for a Better Austin v. Keefe, 402 U.S. 415 (1971)).

42. Cohen, 403 U.S. at 25.

43. Id.

44. See Pacifica, 438 U.S. at 747,747 n.25, 750.

45. See id. at 747.

46. See id.

47. Id. at 748 (emphasis added).

48. See id. By the nature of the medium, even repeated disclaimers, or content disclosure statements, cannot be universally effective for all purposes. See generally R. George Wright, Your Mileage May Vary: A General Theory of Legal Disclaimers, 7 PIERCE L. REV. 85 (2009).

49. Pacifica, 438 U.S. at $748-49$.

50. See Cohen, 403 U.S. at 21 (focusing on effects on privacy interests).

51. Id.

52. Pacifica, 438 U.S. at 749 (emphasis added).

53. See id. ("Other forms of offensive expression may be withheld from the young without restricting the expression at its source"). 
of the children directly, ${ }^{54}$ and second, in supporting the parental claim to childraising authority within the household. ${ }^{55}$ Given the presumed unique pervasiveness of the broadcast media, their unique accessibility to children, and the government interests in child well-being and in supporting parental authority, the Pacifica Court again emphasized contextual factors, including the time of day of the broadcast in question, ${ }^{56}$ along with the technological distinctiveness of broadcasting from a number of other media. ${ }^{57}$ In previous cases, the Court emphasized the scarcity of broadcast frequencies, ${ }^{58}$ presumably not simply in the sense in which most resources are economically scarce, but in the sense that two or more stations broadcasting on the same frequency, unlike two or more newspaper boxes on the same street corner, result in less intelligible speech rather than more. ${ }^{59}$

\section{B. Post-Pacifica Highlights}

Later cases have typically assumed or argued for the continuing vitality of Pacifica's basic logic. Consider, for example, the District of Columbia Circuit's en banc decision in Action For Children's Television v. FCC. ${ }^{60}$ The court, addressing a case of limiting the hours or times of day during which "indecent" material could be broadcast, found that "the government has a compelling interest in protecting children under the age of 18 from exposure to indecent broadcasts." $" 61$ Citing what amounts to a strict scrutiny standard, ${ }^{62}$ the court noted that in Pacifica, "broadcasting . . . received the most limited first amendment protection because of its unique pervasiveness and accessibility to children."63 Then, largely following the analysis in Pacifica, the court majority adopted in particular the interest in supporting parents' supervision of their own children's broadcast media exposure, ${ }^{64}$ as well as the distinct governmental interest in the physical and psychological well-

54. See id. at 749 (relying on the child-standard obscenity case of Ginsberg v. New York, 390 U.S. 629, $639-40(1968))$

55. See id. at 749 (relying on Ginsberg, 390 U.S. at 639-40)

56. See id. at 750 . In this case, oddly, the broadcast was on an October weekday at 2:00 p.m., a time when many children would normally be in school. See id. at 729-30.

57. See id.

58. See Red Lion, 395 U.S. 367, 389-90 (1969). For commentary on Red Lion, see Angela J. Campbell, The Legacy of Red Lion, 60 ADMIN. L. REV. 783 (2008); Ronald J. Krotoszynski, Jr., The Irrelevant Wasteland: An Exploration of Why Red Lion Doesn't Matter (Much) in 2008, the Crucial Importance of the Information Revolution, and the Continuing Relevance of the Public Interest Standard in Regulating Access to Spectrum, 60 ADMIN. L. REV. 911 (2008); L. A. Powe, Jr., Red Lion and Pacifica: Are They Relics?, 36 PEPP. L. REV. 445 (2009).

59. The Red Lion opinion is often taken to have overlooked the economic scarcity of all resources. See e.g., L. A. Powe, Jr., supra note 58, at 446-47 (citing Robert Bork); Ronald J. Krotoszynski, Jr., supra note 58 , at 939 . Whether broadcast frequencies were or are distinctively scarce in some special sense that should be translated into limits on first amendment rights should be far more controversial.

60. 58 F.3d 654 (D.C. Cir. 1995) (en banc) (7-4 decision).

61. Id. at 656 .

62. See id. at 657 (apparently requiring both a compelling governmental interest and the least restrictive available means to promote that articulated interest).

63. Id.

64. See id. at $660-61$. 
being of minors in general. ${ }^{65}$

Judge Harry Edwards' dissenting opinion ${ }^{66}$ expressed uneasiness about the continuing viability of the Pacifica analysis, even as of the year 1995. Judge Edwards, in contrast to the majority, saw cable television as increasingly common, in such a way as to gradually reduce any historic gulf in accessibility or pervasiveness between broadcast television and cable television. ${ }^{67}$ On that basis, Judge Edwards would have reduced the federal regulatory free speech burden on broadcast television to a less intrusive regime, comparable to that of cable television. $^{68}$

Judge Edwards also found that the two asserted governmental interests in this case and in Pacifica (reinforcing parental authority and in shielding children from indecent programming) are actually in conflict. ${ }^{69}$ Judge Edwards found "no evidence that indecent broadcasting harms children."70 Nor did Judge Edwards find, borrowing from strict scrutiny standards, that the FCC had sought out "the least restrictive means" to advance its cited interests. ${ }^{71}$ In each of these respects, Judge Edwards' dissent anticipated important themes that deserve substantially revised and expanded treatment under modern technological circumstances. In crucial respects, as we shall see below, ${ }^{72}$ developments in communications technology, broadly understood, have unforeseeably multiplied the force of Judge Edwards' observations.

The most recent extended treatment of Pacifica, along with the shifting formulations of the associated FCC regulations, took place in Fox Television Stations, Inc. v. FCC, ${ }^{73}$ hereinafter generally referred to as "Fox." In previous incarnations at the Second Circuit ${ }^{74}$ and Supreme Court levels, ${ }^{75}$ Fox was treated, generally, as an administrative law case. The focus has been primarily on whether the FCC's changes in its rules regarding broadcast language, including fleeting

65. See id. at 660-63(in particular, the court references "the coarsening of impressionable minds that can result from a persistent exposure to sexually explicit material just this side of legal obscenity," and the public interest in the "quality" as well as the "health" and full maturing of the nation's youth).

66. See id. at 670 (Edwards, C.J., dissenting).

67. See id. at 671 . Understandably, given the date of the case, Judge Edwards does not discuss the relevance and role of other evolving communications media. For representative cable television regulation cases, see Playboy Entm't Grp, 539 U.S. at 803 (cable "signal bleed" regulations as content-based and thus subject to strict scrutiny); Denver Area Educ. Telecomm. Consortium, Inc. v. FCC, 518 U.S. 727,766 (1996) (plurality opinion) (regulation permitting cable operators to prohibit indecent programming on public access channels as violating free speech clause); Turner Broad. Sys. v. FCC, 512 U.S. 622, 662 (1994) (plurality opinion) (cable television "must carry" regulations as content-neutral and thus subject to intermediate scrutiny).

68. See Action for Children's Television, 58 F.3d at 671 (Edwards, C.J., dissenting).

69. See id. at 672 .

70. Id. at 672. Note that Judge Edwards does not here discuss either other media, or any other conceivably harmful effects of watching any form of television, to whatever extent or degree, including possible effects on learning or on any form of aggressiveness.

71. Id.

72. See infra Section III. B.

73. 613 F.3d 317 (2d Cir. 2010).

74. Fox Television Stations, Inc. v. FCC, 489 F.3d 444, 462 (2d Cir. 2007).

75. Fox Television Stations, Inc. v. FCC, 129 S. Ct. 1800 , 1819 (2009) (Scalia, J., for the Court, reversing the Second Circuit's finding of arbitrariness and capriciousness under the APA and remanding to the Second Circuit for consideration of Fox's first amendment constitutional claims). 
expletives, were sufficiently justified by the FCC to avoid being characterized as arbitrary and capricious under the Administrative Procedure Act. ${ }^{76}$

On remand, and reaching beyond the administrative to the constitutional issue, the Second Circuit held that the then applicable version of "the FCC policy violates the First Amendment because it is unconstitutionally vague, ${ }^{77}$ creating a chilling effect that goes far beyond the fleeting expletives at issue here." 78 The Second Circuit briefly raised a number of First Amendment-related concerns, but rested its holding on the asserted undue vagueness of the relevant FCC policies. ${ }^{79}$

In doing so, the Second Circuit expressed a certain ambivalence. The court announced, forthrightly, that

[W]e are bound by Supreme Court precedent, regardless of whether it reflects today's realities. The Supreme Court may decide in due course to overrule Pacifica and subject speech restrictions in the broadcast context to strict scrutiny. This Court, however, is not at liberty to depart from binding Supreme Court precedent unless and until the Court reinterprets that precedent. ${ }^{80}$

While confining its holding to the issue of FCC policy vagueness, ${ }^{81}$ the Second Circuit took it upon itself to remark on the broader first amendment landscape since Pacifica. In particular, the Second Circuit observed that since the Pacifica decision, there has been "an explosion of media sources, and broadcast television has become only one voice in the chorus. Cable television has become almost as pervasive as broadcast-almost 87 percent of households subscribe to a cable or satellite service . . . ."82 Importantly, the Second Circuit then noted that " $[t]$ he internet, too, has become omnipresent, offering everything from viral videos to feature films and, yes, even broadcast television programs." 83

76. Administrative Procedure Act, 5 U.S.C. $\$ 706(2)(A)$ (2006).

77. For useful studies of vagueness, see Connally v. Gen. Constr. Co., 269 U.S. 385, 391 (1926) (Holmes, J., for the Court) (referring to "terms so vague that men of common intelligence must necessarily guess at its meaning and differ as to its application" as violative of due process); Boyce Motor Lines v. United States, 342 U.S. 337 (1952) (classic discussion of some inescapable tradeoffs with vagueness, precision, experience, expertise, risk, predictability, and the public good in the context of agency-defined crimes); Jeremy Waldron, Vagueness in Law and Language: Some Philosophical Issues, 82 CAL. L. REV. 509 (1994); R. G. Swinburne, Vagueness, Inexactness, and Imprecision, 19 BRIT. J. PHIL. SCI. 281 (1969).

78. Fox, 613 F.3d at 319.

79. See id. at $319,327-35$.

80. Id. at 327 (citations and internal quotations omitted).

81. Our focus herein is not on vagueness issues. It should be obvious that reducing vagueness often imposes costs in terms of other free speech values. One could, in theory, reduce vagueness by always prohibiting only the use of George Carlin's original "seven filthy words." But such an indecency nule would then be objectionable as both over- and under-inclusive. Especially if broadcasters felt some competitive pressure toward less inhibited language, one might expect increasingly frequent and varied evasions of a "seven filthy words" rule. But any response by regulators would then reduce predictability in the application of the rules. For further useful discussion of vagueness, see Trenton Merricks, Varieties of Vagueness, 62 Phil. \& Phenomenological RES. 145 (2001); Keith C. Culver, Varieties of Vagueness, 54 U. TORONTO L.J. 109, 115 (2004) (ten varieties of vagueness); Robert C. Post, Reconceptualizing Vagueness: Legal Rules and Social Orders, 82 CAL. L. REV. 491 (1994).

82. Fox, 613 F.3d at 326 .

83. Id. For a brief sampling of internet and other media first amendment cases, see United States v. Am. Library Ass'n, 539 U.S. 194 (2003) (upholding statute requiring public libraries to use Internet filter 
The latter point deserved development, but the Second Circuit immediately veered off onto an unproductive tangent. The court sought to diminish the realistic scope and magnitude of the regulatory interest and associated first amendment issues by pointing to content control technology such as the V-chip. ${ }^{84}$ The court pointed out that "[e]very television, 13 inches or larger, sold in the United States since January 2000 contains a V-chip which allows parents to block programs based on a standardized rating system." ${ }^{, 5}$ Such a parental content blocking option was thought by the Second Circuit to diminish the severity of the otherwise inescapable First Amendment-related tradeoffs, ${ }^{86}$ though I will implicitly question below the realistic extent of parental control over children's viewing. ${ }^{87}$ In any event, the Second Circuit's holding in Fox, focusing as it does on a narrow finding of unconstitutional vagueness, ${ }^{88}$ stops far short of such concerns. ${ }^{89}$

technologies as a condition for their receipt of federal funding, in light of available means of unblocking access); Reno v. ACLU, 521 U.S. 844 (1997) (holding statutory restrictions on sending "indecent" materials to minors over the Internet to be content-based and facially overbroad); Sable Commc'n v. FCC, 492 U.S. 115 (1989) (limitations on adult access to indecent but not obscene telephone messages could not be justified where unnecessary to promote the compelling interest in shielding minors from such messages); Video Software Dealers Ass'n v. Schwarzenegger, 556 F.3d $950\left(9^{\text {th }}\right.$ Cir. 2009) (striking down state limits on sale or rental of some violent video games lacking serious value on grounds of a lack of compelling governmental interest and lack of narrow tailoring), cert. granted, 130 S. Ct. 2398 (2010); American Amusement Machine Ass'n v. Kendrick, 244 F.3d 572 ( $7^{\text {th }}$ Cir. 2001) (violent video game ordinance as to public play by unsupervised minors as lacking a compelling, as opposed to merely plausible, basis in the evidence).

84. See Fox, 613 F.3d at 326.

85. $I d$.

86. See id. For further discussion, see Brief for Thomas Jefferson Center for the Protection of Free Expression and the Media Institute as Amici Curiae Supporting Petitioners, Fox Television Stations, Inc. v. FCC, 613 F.3d 317 (2d Cir. 2010) (No. 06-1760), available at http:/www.tjcenter.org/wpcontent/uploads/FOX\%20FINAL.pdf .

87. See infra Section III. B.

88. See supra notes 78-82 and accompanying text.

89. See, e.g., sources cited supra note 58 (sampling of the useful law review literature on a range of related regulatory and constitutional issues); Jack M. Balkin, Digital Speech and Democratic Culture: $A$ Theory of Freedom of Expression for the Information Society, 79 N.Y.U. L. REV. 1 (2004); J. M. Balkin, Media Filters, the V-Chip, and the Foundations of Broadcast Regulation, 45 DUKE L.J. 1311 (1996); Robert Corn-Revere, FCC v. Fox Television Stations, Inc.: Awaiting the Next Act, 2009 CATO SUP. CT. REV. 295, 313 (referring in large measure to the Supreme Court-level decision focusing on the issue of the administrative arbitrariness or capriciousness of the FCC's changes of policy and the sufficient reasonableness of the agency's explanation and arguing that "[a]pplying strict scrutiny would bring First Amendment review of broadcast content restrictions in line with the rule for all other media. The Supreme Court has invalidated efforts to restrict indecency in print, on film, in the mails, in the public forum, on cable television, and on the internet") (citations omitted); Ashutosh Bhagwat, What If I Want My Kids to Watch Pornography?: Protecting Children From 'Indecent' Speech, 11 WM. \& MARY BILL RTS. J. 671, 678 (2003) (noting the potential conflicts between the asserted interests in reinforcing parental control of their child's media upbringing and in the public regulatory control of the child's media exposure for the sake of the child's presumed civic and moral fitness and focusing, as the courts typically do, on purportedly indecent as distinct from violent or otherwise allegedly harmful content); Matthew C. Holohan, Politics, Technology, \& Indecency: Rethinking Broadcast Regulation in the 21 $1^{s t}$ Century, 20 BERKELEY TECHNOLOGY L.J. 341,369 (2005) ("[b]ecause cable television and satellite radio enjoy comparable freedom with respect to indecent content, and because these forms of media have become increasingly competitive in the entertainment industry, the time has come to revisit the Pacifica rationale and restore full First Amendment protection to radio and television broadcasters," thus focusing on alleged indecency as distinct from violence and other conceivably detrimental media effects); Brittney Pescatore, Time to Change the Channel: Assessing the FCC's Children's Programming Requirements Under the First Amendment, 33 COLUM. J.L. \& ARTS 81, 85 (2009) ("the supposedly unique attributes of broadcast that the Court initially relied upon wither away in the face of technological change and media convergence"); Stephanie L. Reinhart, Note, The Dirty Words You Cannot Say On Television: Does the First Amendment Prohibit Congress From Banning All Use of Certain 


\section{What CAN Be LEARNED From CuRRENT COMMUNiCATIONS TECHNOLOGIES AND PSYCHOLOGICAL STUDIES?}

\section{A. Introduction to the Problems}

Even a glance at the social science studies regarding the effects of broadcast television and other media on young people indicates a mismatch between the typical focus of judicial attention and the primary focus of social science research. Generally, the judicial focus has been on matters of a sexual nature, including indecency. In contrast, most of the social science studies have focused on forms of aggressiveness, or on one or more dimensions of attentiveness, mood, health, or cognitive learning. ${ }^{90}$ Even where there is relevant social science evidence, social science by itself cannot neutrally answer the important constitutional questions for us in some uncontroversial, value-free way. Suppose for the sake of argument that the courts were to choose to impose a strict scrutiny test on a regulation of the content of broadcast television. The courts would then be looking for a compelling governmental interest to justify the regulation, as well as narrow tailoring, or a precise fit, between the scope or burden of the regulation and the scope of the cited compelling governmental interest. ${ }^{91}$

Each of these two determinations is typically, but unfortunately subject to judicial manipulation within broad limits. ${ }^{92}$ Even if they were not thus manipulable, it remains unclear how much social science evidence should reasonably be required in any given context. In a complex culture, far beyond randomized control groups and the controllability and simplicity of a chemical in a beaker, issues of cause and effect will often be dense, complex, murky, and contested. ${ }^{93}$ To say that one cultural phenomenon clearly, and to some measurable extent, causes another complex cultural phenomenon, to the exclusion of other possible accounts, may well seem dogmatic, irresponsible, or beyond the real capacities of social science.

\footnotetext{
Words?, 2005 U. ILL. L. REV. 989, 1014 (noting that the government interest in shielding children from indecent language is often assumed by courts, at least for the sake of the argument, to be both legitimate and compelling, without much explicit discussion or analysis); Catherine J. Ross, Anything Goes: Examining the State's Interest in Protecting Children from Controversial Speech, 53 VAND. L. REV. 427, 505-06 (2000) (noting the controversiality of any conclusions to be drawn regarding the effects of television violence on minors); Christopher S. Yoo, The Rise and Demise of the Technology-Specific Approach to the First Amendment, 91 GEO. L.J. 245, 355 (2003) (stating that "technological convergence is making it increasingly possible to convey virtually any type of communication through virtually any means of transmission" and citing Butler v. Michigan, 352 U.S. 380 (1957) for the proposition that in order to protect the interests of children, the state cannot "reduce the adult population to reading only what is fit for children"). Actually, the reliance on Butler, as well as on repeated content wamings and even parental control devices on television sets, is also rendered increasingly insignificant by the rapidly changing inter-substitutability of regulated and unregulated media.

90. See infra Section III. C.

91. See cases cited supra note 84.

92. See, e.g., The Limitations of a Common Distinction, supra note 1, at 333; The Fourteen Faces of Narrowness, supra note 10, at 167.

93. See infra Section III. D.
} 
And to judicially defer, or not defer, to a legislative or an administrative agency determination hardly solves this underlying problem. Unfortunately, it is often the most genuinely important issues of social science and public policy that seem the least susceptible of even reasonable degrees of proof. ${ }^{94}$ Yet our "intuitions" are hardly to be trusted either, and may well vary, especially concerning various kinds of media effects. ${ }^{95}$ This is as true for legislatures and agencies as for reviewing courts and their own judicial intuitions.

Ultimately, we can make some real progress in this context not by seeking vainly to reach a consensus on "how much evidence is enough?" or on the extent to which courts should defer to legislative or agency judgment in such matters. Instead, we should take note of the increasingly ineffective nature of typical federal regulations of the content of broadcast television. ${ }^{96}$ However otherwise welljustified such a regulation might be, any remaining substantial burden on any broadcast speaker or viewer can hardly be justified if widely available technologies and cultural practices allow for, and indeed promote, the ready availability of regulated or similar programming to young persons in alternative unregulated venues. We shall see that this is substantially and increasingly the case. ${ }^{97}$ As this ready accessibility in other unregulated media venues continues to increase, the realistic effectiveness of the broadcast regulation further diminishes, and the justification for any significant remaining burden on the content of broadcaster speech diminishes as well.

\section{B. FCC Broadcast Content Regulation as an Anachronism}

Before I briefly consider the state of the social science evidence on media effects, it is crucial to appreciate the remarkable role that various contemporary electronic media play in the daily lives of most young people. Perhaps the most illuminating survey of current patterns of such media use was published in January of 2010 by the Kaiser Family Foundation (hereinafter referred to as the "Kaiser Survey"). ${ }^{98}$

The Kaiser Survey of what we might call the Post-Digital Era contains several remarkable findings. But even its most basic finding is striking: "Eight- to eighteen year olds spend more time with media than in any other activity besides (maybe) sleeping-an average of more than $71 / 2$ hours a day, seven days a week." 99 The broad trends are also remarkable. Between 2005 until 2010, "young people have

94. See id.

95. See, e.g., R. George Wright, The Role of Intuition in Judicial Decisionmaking, 42 Hous. L. REV. 1381 (2006) (discussing both the indispensability of and the inescapable limits of recourse to what is thought of as "intuition").

96. See infra Section III. B.

97. See, id.

98. Victoria J. Rideout, Ulla G. Foehr \& Donald F. Roberts, Generation M²: Media in the Lives of 8- to 18-Year-Olds (2010), http://www.kff.org/entmedia/upload/8010.pdf [hereinafter Kaiser Survey].

99. Id. at 1 . For some purposes, a consumer's simultaneous exposure to more than one medium may be important. In what we might consider a choice of favorably connoted terminology, this is widely referred to as "multi-tasking." Why a term like "multi-diversion" or even "multi-crastination" might not be occasionally more genuinely descriptive is typically left unexplored. 
increased the amount of time they spend consuming media by an hour and seventeen minutes daily, from 6:21 to $7: 38 \ldots . .100$ Given the increase over that time in what is sometimes charitably referred to as "multi-tasking," that $71 / 2$ hour daily average actually includes a separate and combined total of $103 / 4$ hours of media content per day. ${ }^{101}$ These figures, it should be noted, include media consumption uses of cell phones, but do not include either texting or talking on a cell phone. ${ }^{102}$

Most importantly for our purposes, while the consumption of some sort of television content by young people has actually continued to increase, ${ }^{103}$ the technological and social nature of such consumption has changed dramatically. As the Kaiser Survey observes, "[t]elevision content . . . once consumed only by sitting in front a TV set at an appointed hour is now available whenever and wherever [one] wants, not only on TV sets in . . . bedrooms, but on . . . laptops, cell phones and iPods $® ., " 104$ In fact, as of the closing date of the Kaiser Survey, "just $59 \%$ of young people's TV watching occurs on a TV set at the time the programming is originally broadcast: fully $41 \%$ is either time-shifted, or occurs on a platform other than a TV set." "05 This ongoing broad cultural development has obvious implications for the practicality of any attempts at parental control in this regard. ${ }^{106}$ As well, there are the obvious implications for FCC regulations of the specified broadcasting hours of particular kinds of content. ${ }^{107}$ More broadly, there are the implications for the effectiveness of any regulation of broadcast content for young persons when such extreme content is increasingly and conveniently available elsewhere in unregulated formats of increasingly high technological quality. ${ }^{108}$

Any specific description of media interchangeability with, or crossover from, traditional broadcasting is typically rendered quickly obsolete by technological and market developments. Yet the ready availability to young people of nominally regulated broadcast material, or more extreme such material, in various venues and

100. Id. at 2 .

101. See id. For those curious, the average for magazine reading is now down to 9 minutes per day, and for newspaper reading, 3 minutes per day. See id.

102. See id. at 3. It has been estimated that the average American teenager sends over 3,300 texts per month-females more than 4,000 per month, and males more than 2,500 per month, for an overall average of more than six per waking hour, not including voice calls or app usage. See Ben Parr, Average Teen Sends 3,339 Texts Per Month, MASHABLE.COM (October 15, 2010), http://mashable.com/2010/10/14/nielsentexting-stats/. More generally, some of the increase in the use of media may be due to technological changes, including greater screen resolutions or data delivery speeds, while some may be due to an increase in the percentage of young people gaining increasingly unfettered access to a particular item of technology.

103. See id. at 2.

104. Id.

105. Id. at 3

106. See, e.g., Bhagwat, supra note 90 (discussing the relationships among the typically cited regulatory interests).

107. See, e.g., Action For Children's Television v. FCC, 58 F.3d 654, 667 (D.C. Cir. 1995) (en banc) (court approved channeling indecent speech to the hours of midnight to 6:00 a.m. by deferring to historical assumptions regarding the viewing patterns of adults).

108. For an understatement, see Am. Library Ass'n, 539 U.S. at 200, where the court noted that "there is ... an enormous amount of pornography on the Internet, much of which is easily obtained." See generally Kaiser Survey, supra note 99, at 3. 
formats, is clear. This reduces the typically cited federal regulatory state interests to mere empty formalism, while continuing to burden the original broadcaster's First Amendment interests. Any number of relevant internet websites, for example, describe their available content, in general terms or through visitor searches. These sites, beginning with (but extending well beyond) the familiar YouTube ${ }^{109}$ and Hulu, ${ }^{110}$ distribute broadcast television programs, cable television programs, original videos, movies of various sorts, and other programming, creating a general sense of general media fungibility and instant private access. ${ }^{111}$ At this point, virtually any communication device has the potential to bypass or substitute for or utilize any other, with at least for the moment an especially increasing role for the mature adult use of video smart phones. ${ }^{112}$

The realistic, practical effectiveness of FCC content regulation of broadcast media, for whatever asserted public interest, is thus at this point, and increasingly into the future, largely anachronistic, sharply limited, and generally dubious. ${ }^{113}$ Short of a concerted federal effort to reach out, octopus-like, to impose childproofing regulations on all sorts of evolving novel and hybrid and modified media devices and technologies, including smart phones with video capacity, at the likely primary constitutional expense of adults, this is unlikely to change.

\section{The Lessons of Social Science}

But let us assume, against the increasing weight of contemporary technological developments, that FCC content regulation of the broadcast media could today be applied in some realistically effective fashion. We would then be required as judges, legislators, administrators, or citizens to arrive at least at some

109. See YouTUBE, www.youtube.com (last visited Apr. 13, 2011). In yet another dimension of realistically unregulable synergy, Youtube can be pre-installed on some cell phones. YOUTUBE FOR MOBILE, www.youtube.com/mobile (last visited Apr. 13, 2011).

110. See HULU, www.hulu.com/about (last visited Apr. 13, 2011) (in addition to the free version of Hulu, Hulu Plus is available "on smart TVs, gaming consoles, mobile phones, and more" as a subscription service).

111. See, e.g., supra notes $110-11$ and accompanying text; Krotoszynski, supra note 58, at 916 ("[w] hether in print, broadcast, cable, satellite, or Internet form, content is no longer a prisoner to its primary means of distribution").

112. See NiELSEN COMPANY, ThREE SCREEN REPORT (1st Quarter 2010), available at http://www.nielsen.com/content/dam/corporate/us/en/reports-

downloads $/ 3 \% 20$ Screen/2010/Three\%20Screen\%20Report $\% 20(\mathrm{Q} 1 \% 202010)$.pdf (tracking patterns of television, internet, and mobile phone video usage, and finding trends toward the increasing use of technically higher quality versions of all three). It is especially worth noting that "[o]ver half (55\%) of the mobile video audience is age $25-49$, not teens as some might think." Id. at 6 . That most mobile video watching is done by competent adults is constitutionally crucial. See Butler v. Michigan, 352 U.S. 380, 383-84 (1957) (declining to hold adults hostage to free speech interest balancing suitable for children).

113. As for any residual issue of effective parental authority, a Google search on April 24, 2011 of the words: "how bypass parental controls" (without quotations marks) yielded 778,000 results. Among the results, at the time, and admittedly without vouching for efficacy, were How to Get Around Parental Controls on the Internet, WIKIHOW, www.wikihow.com/Get-Around-Parental-Controls-on-the-Internet (admitting to some limitations, but equally clearly a decentralized updateable site); several brief YouTube instructional videos; How to Bypass Parental Controls, THE COMPUTER KID, http://computerkid.blogspot.com/2007/09/how-tobypass-vista-parental-controls.html (followed by 158 viewer comments); several responses under Yahoo! Answers; as well as analogous discussions and videos on bypassing or resetting the V-chip controls on various television models, assuming them to be parentally activated in the first place, noting various possible moves and countermoves. 
vague, tentative, or general sense of the constitutional nature and weight of the various interests at stake. At this moment, we can say that quite a number of methodologically varied studies have been done on several sorts of possible media effects on young persons of various ages. There are a relatively small number of studies regarding the effects of violent video games, ${ }^{114}$ but a greater number on television viewing and some measures of aggressiveness, ${ }^{115}$ hostility, violence, or effects on mood, cognition, attention, health, or learning, short or long term. ${ }^{116}$

114. See Christopher J. Ferguson et al, Violent Video Games, Catharsis Seeking, Bullying, and Delinquency: A Multivariate Analysis of Effects, 20 CRIME \& DELINQ. 1, 1, 4 (2010) (observing that "[v]iolent video game exposure was not found to be predictive of delinquency or bullying" and that "[o]verall, results of violent video game research have been mixed"); Patrick M. Markey \& Charlotte N. Markey, Vulnerability to Violent Video Games: A Review and Integration of Personality Research, 14 REV. GEN. PSYCHOL. 82, 82, 90 (2010) (finding that "only some individuals are adversely affected by [violent video games] and ... those who are affected have preexisting dispositions, which make them susceptible to such violent media" and that "the vast majority of individuals exposed to [violent video games] do not become violent in the 'real world."'); Cheryl K. Olson et al., M-Rated Video Games and Aggressive or Problem Behavior Among Young Adolescents, 13 APPLIED DEVELOPMENTAL SCI. 188, 188, 194-95 (2009) (finding that "M-rated game dose predicted greater risk for bullying ... and physical fights . . , but not for delinquent behaviors or being a victim of bullies. When analyzed separately, these associations became weaker for boys and stronger for girls," that "most young adolescents who play M-rated games are neither bullies nor victims," and that "[i]t is likely that any influence of violent games is mediated by a child's individual characteristics, experiences, and environment, including discipline, supervision and affection from parents; affiliation with antisocial peers; and family or community violence"); Jeanne B. Funk et al., Violence Exposure in Real-Life, Video Games, Television, Movies, and the Internet: Is There Desensitization?, 27 J. ADOLESCENCE 23 (2004) (exposure to video game violence as associated with more pro-violent attitudes and lesser empathy); L. Rowell Huesmann, Nailing the Coffin Shut on Doubts That Violent Video Games Stimulate Aggression: Comment on Anderson et al. (2010), 136 PSYCHOL. BULL. 179 (2010) (referring to the meta-analytical study by C. A. Anderson et al., Vialent Video Game Effects on Aggression, Empathy, and Prosocial Behavior in Eastern and Western Countries, 136 PsyCHOL. BuLL. 151 (2010)). We might note, however speculatively, that many popular violent video games require active decisionmaking on the part of the player, or "shooter," as opposed to some other forms of media violence, however emotionally involving, or however strongly a viewer might identify with a violent character.

115. See George Comstock, A Sociological Perspective on Television Violence and Aggression, 51 AM. BEHAV. SCIENTIST 1184, 1192, 1200 (2008) (referring to "persistent positive correlations between exposure to violent television entertainment and aggressive or antisocial behavior" with "a causal contribution by television" and noting that "[o]utcomes that are more seriously harmful or criminal have much smaller effect sizes, but they are statistically significant and represent the infliction of greater harm than merely hitting, fighting, name-calling, or stealing"); Betty Jo Simmons et al., Television Violence and Its Effects on Young Children, 26 EARLY CHILDHOOD EDUC. J. 149, 152 (1999) (linking television violence with aggression, but interestingly, with respect to constitutional "narrow tailoring" issues, recommending six separate strategies in response, all six of which focus on parental behavior, school curricula, and community programs as distinct from official speech-restrictive government broadcast regulatory policy). See also L. Rowell Huesmann et al., Longitudinal Relations Between Childhood Exposure to Media Violence and Adult Aggression and Violence: 1977-1992, 39 DEVELOPMENTAL PSYCHOL. 201, 219 (2003) (recommending parental co-viewing and commenting on the programs in order to reduce their effects).

116. See Carl Erik Landhuis et al., Does Childhood Television Viewing Lead to Attention Problems in Adolescence? Results From a Prospective Longitudinal Study, 120 PEDIATRICS 532, 533 (2007) ("[T]he mean of hours of television viewing during childhood was associated with symptoms of attention problems in adolescence. These associations remained significant after controlling for gender, attention problems in early childhood, cognitive ability at 5 years of age, and childhood socioeconomic status. This association was also independent of adolescent television viewing"); Daniel R. Anderson \& Tiffany A. Pempek, Television and Very Young Children, 48 AM. BEHAV. SCIENTIST 505, 505 (2005) (most such studies as finding negative associations between such youthful viewing and "language, cognitive, and attentional development"); Dimitri A. Christakis et al., Early Television Exposure and Subsequent Attentional Problems in Children, 113 PEDIATRICS 708, 708 (2004) ("hours of television viewed per day at both ages 1 and 3 was associated with attentional problems at age 7"). For a brief but intriguing broader survey of possible adverse effects of television viewing more generally, see Jerome L. Singer, TV View: Why Johnny's Watching Needs Watching, 
Relatively little rigorous work has been done on effects of purportedly indecent television or radio content, and television's effects on mood, cognition, health, attention, and learning do not appear to be the focus of FCC indecency or violence regulation. $^{117}$

No single study can be definitive, but a coherent picture of even complex social phenomena can begin to emerge if a mass of studies, perhaps of different sorts, ${ }^{118}$ with different strengths and weaknesses, can be combined in a statistically

N.Y. TIMES (Apr. 9, 1989), http:/www.nytimes.com/1989/04/09/arts/tv-view-why-johnny-s-watching-needswatching.html. For further intriguing articles, none of which seems much reflected in actual or proposed FCC broadcast content regulation, see Robert Kubey \& Mihaly Csikszentmihalyi, Television Addiction Is No Mere Metaphor, SCIENTIFIC AM. (February 23, 2002), http://www.scientificamerican.com/article.cfm?id=televisionaddiction-is-n-2002-02. More favorable articles also exist. See Marie-Louise Mares \& Emory Woodard, Positive Effects of Television on Children's Social Interactions: A Meta-Analysis, 7 MEDIA PSYCH. 301,316 (2005) ("the results suggest that television is no more prone to fostering violence than it is to fostering prosocial behavior"); Common Sense Media, Media + Child and Adolescent Health: A Systematic Review 2 (Nov. 2008), http://www.commonsensemedia.org/sites/default/files/CSM_mediathealth_v2c\%20110708.pdf (meta-analysis of 173 studies of media, not limited to television, which concluded that " $[\mathrm{i}] \mathrm{n} 80 \%$ of the studies, greater media exposure is associated with [broadly defined] negative health outcomes for children and adolescents," including childhood obesity).

There are also studies of media violence on children and adolescence in which the emphasis is on the media in general, as distinct from merely television, or some other particular entertainment medium. See, e.g., Craig A. Anderson et al., The Influence of Media Violence On Youth, 4 PSYCHOL. SCl. PUB. INT. 81,81 (2003) (referring to "unequivocal evidence that media violence increases the likelihood of aggressive and violent behavior in both immediate and long-term contexts," although the effects are greatest for the milder forms of aggression); M.L. Ybarra et al., Linkages Between Internet and Other Media Violence with Seriously Violent Behavior by Youth, 122 PEDIATRICS 929, 929 (2008) ("Exposure to violence in the media, both online and offline, were associated with significantly elevated odds for concurrently reporting seriously violent behavior"); Douglas A. Gentile et al., Media Violence as a Risk Factor for Children: A Longitudinal Study 2 (paper presented at the May 2004 American Psychological Society $16^{\text {th }}$ Annual Convention), available at http://www.psychology,iastate.edu/ dgentile/pdfs/Gentile_et_al_APS_2004.pdf ("Children who consumed more media violence early in the school year were more verbally aggressive, relationally aggressive, and physically aggressive later in the school year" as determined by self-report, peer nomination, and teacher nomination).

117. Just as the FCC does not have the authority to regulate all media for indecency or violence, neither does the FCC typically seek to broadly regulate any medium, including broadcast television, beyond vague "educational" programming requirements, for its potential adverse effects on learning, attention spans, cognition, or psychological or physical health. See generally Pescatore, infra note 135.

118. See supra notes 115-117 (examples of meta-analyses). A number of compilations and popular books collecting references to studies and broader critiques of television and other entertainment media, on a variety of grounds, also prove illuminating. See JANE M. HEALY, ENDANGERED MindS: Why ChILDREN DON'T THINK-AND WHAT We CAN Do ABOUt IT 216 (1999 ed. 1990); MAGGIE JaCKSON, Distracted: The EROSION OF ATTENTION AND THE COMING DARK AGE 72-73 (2009) ("television is in essence an interruption machine"); JERRY MANDER, FOUR ARGUMENTS FOR THE ELIMINATION OF TELEVISION 274 (2002 ed. 1978) (referring to a "bias toward the coarse, the bold, and the obvious"); NEWTON N. MINOW \& CRAIG L. LAMAY, ABANDONED IN THE WASTELAND: CHILDREN, TELEVISION, AND THE FIRST AMENDMENT 28 (1995) (referring to studies of the effects of television violence); NeIl Postman, Amusing Ourselves to Death: PubliC DisCOURSE IN THE AGE OF SHOW BusINESS 16, 92 (2005 ed. 1985) (describing public discourse under the "governance" of television as "shriveled and absurd" and noting that "[i]t is in the nature of the medium that it must suppress the content of ideas in order to accommodate the requirements of visual interest; that is to say, to accommodate the values of show business"); ARIC SIGMAN, REMOTELY CONTROLLED: HOW TELEVISION IS DAMAGING OUR LIVES 100-01 (2005) (unfavorably comparing the brain-stimulation effects of television to those of reading); MARIE WINN, THE PLUG-IN DRUG: TELEVISION, COMPUTERS AND FAMILY LifE 7, 11 (2002 ed. 1977) (discussing some of the effects of television viewing on children's verbal abilities and behavior). For a useful if occasionally dated broad collection of more technical papers, see HANDBOOK OF CHILDREN AND THE MEDIA (Dorothy G. Singer \& Jerome L. Singer eds. 2001). As a mere thought experiment, imagine trying to draft a constitutionally enforceable media regulation aimed at discouraging anything like sheer coarseness, inanity, vulgarity, tawdriness, or vacuousness of a broadcast or other form of entertainment. See Elizabeth Guider, Primetime TV Shows to Get Racier After Court Ruling, Reuters.COM (July 16, 2010), 
responsible way. Equally clearly, of course, a correlation between phenomena $\mathrm{A}$ and $B$ does not by itself tell us which, if either, causes the other.

\section{The Limitations of Social Science}

But for our purposes, the direction of lines of causation really does not loom as a major problem. ${ }^{119}$ Nor is a lack of any detectable correlation of much concern. The social science evidence often, though hardly invariably, turns up some limited degree of correlation, often with a number of other possible causal factors somehow controlled for. ${ }^{120}$ Often, we can reasonably infer that some phenomenon $A$ is correlated with, and perhaps to an extent tends to cause, B. One problem, though, is that A's causal influence on B may be clear, but relatively weak, and shared with a large number of other, perhaps related causal factors. ${ }^{121}$ And even if we can be certain that $\mathrm{A}$ has some modest role in causing $\mathrm{B}$, there can be no guarantee that effect B-which may be merely fifteen minutes of paper and pencil-expressed crabbiness in an artificial laboratory setting-fairly represents, or even sheds much light on, any problem or governmental interest that could be called "compelling." There is a clear difference between the concerns raised by moodiness, crabbiness, or schoolyard rowdiness and those raised by things like violent crime. National rates for serious crime are then even further removed. ${ }^{122}$

In any event, the main problem facing government regulation of broadcast content is at most one of the required degrees of proof, or of the contestable application of strict scrutiny. Instead it is, as I have noted, the increasing and already substantial intersubstitutability of various media, with the relevant content being easily accessible in various private formats to young people and adults. Traditional content regulation models become irrelevant as technological and other cultural developments promote nearly unconstrained media content access. ${ }^{123}$

This is certainly not to dismiss the concerns that responsible media critics have raised, beginning at least from the time of Plato. Plato's account of his ideal society, whatever the media involved, seems in its essentials clear:

[W]e must . . compel our poets, on pain of expulsion, to make their poetry the express image of noble character. . . We would not have our Guardians [rulers] grow up among representations of moral deformity, as in some foul pasture where, day after day, feeding on

http://uk.reuters.com/article/2010/07/16/television-us-primetime-idUKTRE66F0K820100716.

119. See works cited supra notes 116-17 (discussion of various methodological limitations).

120. See studies cited supra notes 116-17.

121. See id. See generally Jim Manzi, What Social Science Does-and Doesn't-Know, CiTY JouRNAL (Summer 2010), http://www.city-journal.org/2010/20_3_social-science.html. See also Tom Siegfried, Odds Are, It's Wrong: Science Fails to Face the Shortcomings of Statistics, ScIENCENEwS (Mar. 27, 2010), www.sciencenews.org/view/feature/id/57091; David H. Freedman, Lies, Damned Lies, and Medical Sciences, ATLANTIC MAGAZINE (Nov. 2010), http://www.theatlantic.com/magazine/archive/2010/11/lies-damned-liesand-medical-science/ 8269 .

122. See supra notes 116-117.

123. See supra Section III. B. 
every poisonous weed they would, little by little, gather insensibly a mass of corruption in their very souls. ${ }^{124}$

Such straightforward illiberalism is plainly contrary to our most basic first amendment jurisprudence, and should not constrain our First Amendment jurisprudence. At the same time, though, we cannot be so arrogant as to assume that a strong and consistent devotion to first amendment principles involves no possible social and cultural costs. Consider the valuable perspective of contemporary philosopher Simon Blackburn:

Before we mock Plato we may also reflect on our consumption of art. The average American eighteen year old, it is said, is likely to have watched something like 18,000 murders on TV. Although social science finds it almost impossible to speak with one voice about anything, there is good evidence that this relentless diet not only desensitizes young people, but makes them more fearful (and for that matter, more stupid). Dramatic representations give us patterns which we can follow, and the question of how far children or grown-ups do follow them is an empirical one. Studies appear to vary, and no doubt the contagion varies with many factors, but it is hard to believe that there is none at all. Perhaps Plato is right and our minds are imitative. .. . We cannot patronize Plato from a position of wisdom or success in knowing how to feed people's minds. ${ }^{125}$

Blackburn rightly emphasizes both the difficulty in clearly linking the worst social outcomes, in any large measure, to some particular content of some particular medium, and our vague, uncodifiable uneasiness at the cumulative effect of any communications medium, or of popular entertainment and heavily commercialized media in general. ${ }^{126}$

In certain moments, some of us may feel that we intuitively know more than we can tell about the effects of entertainment and commercial media, including possible harms. ${ }^{127}$ We can, however, hardly pretend that our collective intuitions as

124. Plato, The Republic of Plato ch. IX, $\S 3$, at 90 (Francis M. Cornford trans. 1990 ed.) (n.d.) (on the primary education of the Guardians).

125. SIMON BLACKBURN, Plato's REPUBLIC: A BIOGRAPHY 62-63 (Atlantic Books 2006) (emphasis in original).

126. For further references to Plato's extended discussion of the effects of the arts, see JULLA ANNAS, AN Introduction to Plato's Republic 338 (Oxford Univ. Press 1981); ERnest Barker, The Political THOUGHT OF PLATO AND ARISTOTLE 129 (1959 ed.) (1906) ("art should always convey a moral message"); R. C. Cross \& A. D. Woozley, Plato's Republic: A Philosophical Commentary 238 (1966) (Plato "believed that the audience identified themselves with the characters on the stage, in this sense imitated them, and that this imitation had an effect on their own character and actions"); 2 WERNER JAEGER, PAIDEIA: THE IDEALS OF GREEK Culture 227 (Gilbert Highet trans., Oxford Univ. Press 1986 ed.) (1943) ("only those modes are allowed which express the ethos of a brave or temperate man"); RICHARD LEWIS NETTLESHIP, LeCTURes ON THE REPUBliC OF Plato 108 (Univ. of the Pacific 2003 ed.) (1888) ("[n]o art ... can help being educational; it affects character because it expresses character"); C.D.C. REEVE, PHILOSOPHER-KINGS: THE ARGUMENT OF PLATO'S REPUBLIC 225 (Hackett Publ'g 1988) (the "wise and calm" character as not making for good popular theater); Eric Voegelin, PLATO 131-32 (Univ. of Missouri 2000 ed.) (1957); JESSICA Moss, What Is ImItative Poetry and Why Is IT BAD?, In THE Cambridge Companion to Plato's REPublic 415, 442 (G.R.F. Ferrari ed., Cambridge Univ. Press 2007); James O. URMSON, Plato and the PoEts, IN Plato's Republic: Critical EsSays 223, 229 (Richard Kraut ed., Rowman \& Littlefield Publishers 1997) ("in the theater we are led to admire what outside of it is we would despise").

127. Many academics have explored the idea of our "knowing" what we cannot prove, or even articulate. See, e.g., EDMUND BURKE, REFlections ON THE REVOlution IN FRaNCE (L.G. Mitchell ed., Oxford Univ. Press 2009) (1790); Michael OAKeshotT, Rationalism IN POlitics and Other Essays (Liberty Fund 
to the degree of harm of speech regulated for its content are unanimous. ${ }^{128}$ Nor does social science typically present us with unequivocal answers at a level of specificity we would find most useful. ${ }^{129}$ This is especially so given what has been called the "causal density," or the complex network of contributing causes, of the social phenomena of greatest interest. ${ }^{130}$ And certainly, this causal density problem does not disappear when we examine the possible consequences of particular media, or of entertainment and commercial media in general. ${ }^{131}$

\section{CONCLUSION}

As we have seen, the policy logic underlying Pacifica-type regulations of the content of broadcast television and radio, whatever its initial strength, has, in our Post-Digital Era, disintegrated nearly completely. As the Second Circuit has recently observed, the lower courts are not free to simply announce that otherwise relevant Supreme Court case law has been superseded by technological developments. ${ }^{132}$ But the by now almost complete intersubstitutability of various media, entailing the ready accessibility for adolescents of programs more objectionable to many adults than the broadcast material subject to regulation, proceeds regardless. The patent ineffectiveness of broadcast content regulations renders moot any debates over manipulable criteria such as the proper scope of strict scrutiny, what should count as a compelling governmental interest, and whether a given rule is sufficiently narrowly tailored or unduly vague. ${ }^{133}$

It might be asked, though, whether federal broadcast regulators could concede this argument, but then stand the argument on its proverbial head. Yes, the sorts of content the government might wish to regulate are realistically available, via one medium or another, to persons of nearly all ages. But, the argument would run, the sheer pervasiveness of such content - a culture that is awash in such entertainment and commercial content-provides a reason in favor of something like traditional broadcast regulation. The idea would instead be for federal broadcast content regulation to provide for a safe haven; an island; an oasis; a refuge-a shelter from the assumedly dominant popular cultural trends. ${ }^{134}$

expanded ed. 2010) (1962); Michael POLANYI, THE TACIT DIMENSION (Doubleday \& Co. reissue ed. 2009) (1966). On the philosophical doctrine of intuitionism, see ETHICAL INTUITIONISM: RE-EvaluatIONS (Philip Stratton-Lake ed., Oxford Univ. Press 2003).

128. It was, for example, the clear and sustained intuition of comedian George Carlin, and presumably much of his audience, that the broadcasting of the Seven Filthy Words was essentially harmless. See FCC v. Pacifica Found., 438 U.S. 726, 751-55 (1978).

129. See Manzi, supra note 122.

130. Id. (" $[\mathrm{A}] \mathrm{s}$ experiments began to move from fields like classical physics to fields like therapeutic biology, the number and complexity of potential causes of the outcome of interest--what I term "causal density"--rose substantially")

131. See id.; BLACKBURN, supra note 126, at 62-63.

132. See Fox Television Stations v. FCC, 613 F.3d 317, 327 (2d Cir. 2010).

133. Id. at 327-35 (vagueness discussion). There are inevitable costs when rules are rendered less vague and more precise and predictable. See sources cited supra notes 78,82 .

134. This general idea, and in particular the language of a "relatively safe haven," is the work of Justice Scalia. See FCC v. Fox Television Stations, Inc., 129 S. Ct. 1800, 1819 (2009). See also Brittney Pescatore, 
In any event, the central image of the argument is perhaps one of a parent and child being able to sit down together to watch a broadcast channel program, in real time, at a reasonable hour, with some assurance that sex, sexual references, or extreme violence need not be anticipated. A "safe haven" from precisely what kind or kinds of content might not, however, be clear at the federal regulatory level. Furthermore, precisely when an "island" of shelter becomes a vast (and arguably repressed) continent, with high costs to the freedom of the broader society, might also at some point arise as an issue.

But the basic problems with such a "safe haven" regulatory rationale are really twofold. First, such a rationale largely abandons the traditional concern for the purported well-being of children, or of the broader culture in general. The goal is no longer, apparently, that of sheltering most young persons from assumedly inappropriate content; that historic goal has by concession become technologically and culturally unrealistic. The goal is instead now much narrower, however appealing the sheltered parent-child joint viewing scenario may be to some.

Second, and far more constitutionally important, though, is that whatever value inheres in such joint "safe haven" viewing scenarios has been, is now, and presumably would remain available, as described above or in some more or less equivalent way, even in the absence of any Pacifica-style broadcast content regulations. Safe haven-based federal regulations are plainly unnecessary in practice. However a parent chooses to define "harmless," some harmless family viewing possibilities, ${ }^{135}$ in one format or another, or some combination of formats and media, would survive the abolition of Pacifica-type regulations. In a Youtube world, some content-creators and content-aggregators will respond to any significant interest in any sort of content deemed by some to be unobjectionable, in low cost, easily accessible ways.

This is not a question of lack of any narrow tailoring ${ }^{136}$ of such a "safe haven" regime to its new and narrowed regulatory purpose. The constitutional problem, more directly, is that such a broadcasting "safe haven" rule would burden the speech rights of broadcasters, while at the same time being, as a practical matter, entirely unnecessary. With or without any sort of Pacifica-type broadcast rules, we can confidently anticipate that content unobjectionable to most parents ${ }^{137}$ would continue to be available in one form or another of television, DVD or successor media, or the Internet. ${ }^{138}$ Tastes and standards vary widely, as does correspondingly

Time to Change the Channel: Assessing the FCC's Children's Programming Requirements Under the First Amendment, 33 COLUM. J.L. \& ARTS 81, 108 (2009). For an earlier case touching upon some very loosely similar concerns, see FCC v. WNCN Listeners' Guild, 450 U.S. 582 (1981) (judicially deferring to the FCC's format diversity policy of allowing local market demand for particular kinds of radio programming to override a purported public interest in, or private preference for, preserving a radio station's classical music format).

135. Of course, a conscientious parent could object to all television, public or commercial, broadcast or otherwise. Indeed, there are a number of possible concerns that can be raised. See works cited supra note 119. But such "abstainers" would presumably not in all cases be satisfied by any Pacifica-style regulatory regime either.

136. See supra note 93 and accompanying text.

137. We set aside here the scenario of a parent and child reading, together, any unobjectionable book.

138. This point seems inherently so plainly right that any attempt to cite evidence will add little. But consider, merely as suggestive, a few almost randomly chosen items of support: As of September, 2010, the top domestic grossing films of all time, adjusted for inflation, were, in descending order, Gone With the 
available media content. Legal regulation for the sake of preserving any sort of a safe haven is thus plainly unnecessary. ${ }^{139}$ Thus even on the most creative theories, Pacifica-type broadcast content regulations have outlived their day.

Wind; Star Wars IV; The Sound of Music; E.T.; The Ten Commandments; Titanic; Jaws; Doctor Zhivago; The Exorcist; Snow White and the Seven Dwarfs; 101 Dalmations; Star Wars V; and Ben Hur. See Box OFFICE TOP 100 FILMS, www.filmsite.org/boxoffice.html (last visited Apr. 13, 2011). These may appeal to an older audience, even generationally, but even if few or none of them is deemed appropriate, parents are still not then without many options. Consider, for example, a list of leading DVD format rentals worldwide, compiled from IMDb charts. Certainly, a number of such entries would be rated PG-13. See DVD Rentals: USA Weekly Top 20, IMDB, http://www.imdb.com/boxoffice/rentals (last visited Apr. 13, 2011). But somewhere within such a list, and presumably realistically available in one format or another, would be entries such as the various Toy Story movies; Alice in Wonderland; various Lord of the Rings; Harry Potter; Star Wars; Shrek; and Ice Age entries; Finding Nemo; The Lion King; E.T.; The Chronicles of Narnia; Up; Kung Fu Panda; The Incredibles; Ratatouille; Night at the Museum; Aladdin; How to Train Your Dragon; Charlie and the Chocolate Factory; and The Little Mermaid. And all of these entries set aside any appropriate Youtube-type material, as well as anything that could reasonably be classed as educational, including fitness or yoga videos, biographies, religious material, or documentaries for various age groups on history, sports, or nature (discounting, just personally, a particular Youtube video of a sneezing baby panda which has been apparently, if inexplicably, viewed 80 million times). For the foreseeable future, cable and satellite television in particular also present the option of what particular parents might well consider to be "dedicated" reliable channels of predictably acceptable content.

139. In the altemative, we could consider utterly unnecessary or pointless regulation of speech not only to lack narrow tailoring, but also to not significantly advance any genuine public interest, of whatever weight. 